\title{
Evaluation of Production Efficiency using Data Envelopment Analysis at PT. Perkebunan Nusantara XI
}

\author{
Dewie Saktia Ardiantono*, Syarifa Hanoum, Febi Murdianti, \\ Department of Business Management, Institut Teknologi Sepuluh Nopember, Surabaya, Indonesia \\ *Corresponding author. Email: dewie@ mb.its.ac.id
}

\begin{abstract}
This study develops an evaluation of production efficiency at PT Perkebunan Nusantara XI. Since the domestic sugarcane-based industry today faces many challenges of change. From 2017 through 2018, Indonesia became the largest importer in the world. The high demand for sugar imports is caused by national production that has not met domestic needs. PTPN XI is a state-owned enterprise (SOEs) engaged in agribusiness with the core business of producing sugar. At present, PTPN XI has a problem, which is decreasing production efficiency. This study attempts to design and identify the measurement indicators used to evaluate the production efficiency of PTPN XI using Data Envelopment Analysis. The research objective will be accomplished through the analysis of questioners filled by the expert in the company. Based on the calculations and peer group decisions obtained by several factories that are being referenced, including the Pagottan Sugar Factory, Panji, Prajekan, Wonolangan, and Wringin Anom. Variables that significantly affect the efficiency of PT Perkebunan Nusantara XI's sugar mills are labor, electricity costs, and production capacity variables.
\end{abstract}

Keywords: Data envelopment analysis, production efficiency, sugar production

\section{INTRODUCTION}

Today's domestic sugarcane-based industries face many challenges of change. In the 1930s, Indonesia was the second-largest sugar exporter in the world, with a production of 3 million tons per year [1]. However, [2] says that Indonesia became the largest sugar importer globally in the 2017-2018 period, with a total sugar import of 4.45 million tons. The high amount of sugar imports is caused by national production, which is insufficient to meet the needs of increasing sugar consumption [3]. 4] mention that in the last five years (2014-2018), the amount of national sugar demand has always increased, but domestic sugar production has consistently declined. The main constraints are the low quality of raw materials, the small capacity of some factories, the factory's low efficiency, the long hours of stopping, and high production costs [5].

PT Perkebunan Nusantara XI is one of the state-owned enterprises (SOEs) in agribusiness industry. The core business of PTPN XI is producing or processing sugar. It contributes around $16-18 \%$ to national production [6]. PT Perkebunan Nusantara XI also has problems related to decreased production efficiency. According to [7],the performance of PTPN is very far behind compared to the private sector. This inefficiency results in sugar production being unable to meet domestic needs. Performance measurements at PT Perkebunan Nusantara $\mathrm{XI}$ are carried out with various criteria in each division. So, it cannot be done centrally. Efficiency measurements at PT Perkebunan Nusantara XI consist of measuring mill efficiency and plant efficiency. With the existing measurement method, it is not known for overall factors 


\section{Procedia Business and Financial Technology}

Proceedings of the 2nd International Conference on Business and M anagement of T echnology (ICO N BM T 2020) - Part 2

that can cause inefficiency problems. Using the Data Envelopment Analysis (DEA) method, the performance measurement (production efficiency) can be carried out as a whole involving various components.

In this study, an evaluation of production efficiency will be carried out using a linear programming technique called Data Envelopment Analysis (DEA) to measure the Decision-Making Unit (DMU).

\section{LITERATURE REVIEW}

\section{A. Efficiency-Based Performance Measurement}

Efficiency is one of the performance parameters that underlie an organization's entire performance [8]. Efficiency is a measure that shows how useful economic resources are in the production process to produce output. Identifying the allocation of inputs and outputs can be performed to determine the causes of inefficiency. A company's efficiency consists of two components, namely, technical, and allocative efficiency [9]. So, it can be concluded that an organization can be efficient if the output produced can be increased without adding or increasing inputs and decreasing certain other outputs.

\section{B. Data Envelopment Analysis (DEA)}

Data Envelopment Analysis (DEA) is a mathematical programming technique based on linear programming that is used to evaluate the efficiency of a decisionmaking unit (work unit) that is responsible for using several inputs to obtain a targeted output [10]. This measurement is expressed by the output/input ratio, which measures efficiency or productivity. DEA allows us to calculate the overall cost efficiency (CE), technical efficiency (TE), allocative efficiency (AE), pure technical efficiency (PFE), and scale efficiency (SE) [11]. DEA's ability to identify units used as a reference can help determine causes and solutions to inefficiencies. In measuring efficiency using DEA, two models are often used, namely:

\section{1) Constant Return to Scale (CRS)}

This DEA model was first introduced by [12], an inputoriented model based on the assumption of constant return to scale so that it is known as the CCR model. Assuming that DMU operates at an optimal scale. To determine the optimal weights done using mathematical programming as follows:

Max $h \mathrm{n}=\sum \mathrm{j} u \mathrm{j} y \mathrm{j} \mathrm{n}$

Subject to $\sum \mathrm{i}$ vi $x$ in $=1$

$\sum \mathrm{j} u \mathrm{j} y \mathrm{jn}-\sum \mathrm{i} v \mathrm{i} x \mathrm{in} \leq 0$

$u \mathrm{j}, \mathrm{v} \leq \varepsilon(1)$
The value of technical efficiency in DEA identifies inefficient units and the degree of inefficiency. DEA provides an estimated efficiency increase target for inefficient DMUs in the form of increased output values which are mathematically formulated in the following equation:
$\mathrm{x}^{\prime}$ ino $=\mathrm{xino}-\mathrm{ISi}$
$y^{\prime}$ ino $=\theta * y$ jno + OS $\mathbf{J}(3)$

Whereas the other approach, namely Input Oriented DEA, provides a target in the way of a decrease in the input value.

\section{2) Variable Return to Scale (VRS)}

This assumption model is a variable return to scale, which means that the addition of inputs by $\mathrm{x}$ times will not cause the output to increase by $\mathrm{x}$ times, can be smaller or larger. The return to scale variable describes the overall technical efficiency consisting of two components: pure technical efficiency and scale efficiency. The DEA-CRS linear program can be easily modified into the DEA-VRS model by adding convexity constraints to the following equation:

$\sum \mathrm{n} \lambda \mathrm{n}=1$

The use of CRS specifications where DMUs are not operating at an optimal scale will result in a measure of technical efficiency (TE) being defeated by scale efficiency (SE). In other words, the value of technical efficiency (TE) obtained from the DEA-CRS formulation (TECRS) can be decomposed into two components, namely: 'pure' technical efficiency (TEVRS) and scale efficiency (SE).

$\mathrm{SE}=\mathrm{TE} € \mathrm{RS}$

TEVRS (5)

\section{METHOD}

Five main stages will be carried out in this study, consisting of the preparation stage, model specifications, data collection, model implementation, and the final step. 1) Preparation Stage

a. Identification of existing company conditions related to vision and mission, business processes, performance measurement, efficiency measurement.

b. Identification of research formulation of evaluation of production efficiency in all plant units, which is where the production efficiency

.




\section{Procedia Business and Financial Technology}

Proceedings of the 2nd International Conference on Business and M anagement of T echnology (ICO N BM T 2020) - Part 2

valuation is done on a series of business processes carried out at each factory unit.

c. Conduct literature studies related to previous research on measuring or assessing production efficiency in the sugar industry by using Data Envelopment Analysis (DEA) and analyzing comparisons or differences between previous study and research to beconducted.

\section{2) Model Specification}

The following will discuss the specifications of the study's model, consisting of four stages as follows:

a. Identification of the factory unit (Decision Making unit / DMU), which will be evaluated for production efficiency. 13 units of factories (Decision Making Unit / DMU) are still operating or producing crystal sugar and then to be evaluated for production efficiency.

b. Determination of the function of the objectives to be achieved by the company. The company aims to make Output-DEA, which measures technical efficiencyas a proportional increase in output.

c. Determination of input and output variables. Input variables used are land area (X1), some milled sugarcane (X2), production capacity (X3), electricity costs (X4), and total labor (X5). The output variable used is the amount of crystalline sugar production (Y1).

d. Develop a mathematical model or formulation of the Data Development Analysis (DEA) method.

\section{3) Data Collection}

Data collection is done by distributing data collection forms to the head of the division which consists of the Division of Human Resources, Plants, Processing, and Engineering.

\section{4) Model Implementation}

This model's implementation consists of the DEA mathematical model formulation, the calculation of relative efficiency, the analysis of DEA variables, analysis, and discussion. The provision of strategy recommendations at this stage is based on the results of data processing and analysis.

5) DEA Mathematical Model Formulation

a. Technical Efficiency (TE)

Efficiency or technical efficiency (TE) values are calculated using a DEA mathematical model based on a constant return to scale (TECRS), in the form of technical efficiency $=$
1 if the DMUs are efficient, and $<1$ if inefficient, so that an efficient and inefficient factory unit can be determined.

. The structure of the mathematical formulation can be seen in the following equation:

Objective Function:

$\operatorname{Max}: \theta \mathrm{n}+\varepsilon\left(\sum \mathrm{i} S \mathrm{i}+\sum \mathrm{j} O S \mathrm{j}\right)$

Constraints:

Output 1 : Amount of production $\sum \mathrm{n} y 1 \mathrm{n} \lambda \mathrm{n}-\theta \mathrm{y}-\mathrm{n}$ $10 \mathrm{oS}=0$

Input 1: The amount of sugar cane milled $\sum \mathrm{n} x \ln \lambda \mathrm{n}+$ IS $1=x 10$

Input 2: Amount of worker $\sum \mathrm{n} x 2 \mathrm{n} \lambda \mathrm{n}+\mathrm{IS} 2=x 2 \mathrm{o}$

Input 3: Fuel costs $\sum \mathrm{n} x 3 \mathrm{n} \lambda \mathrm{n}+\mathrm{IS} 3=x 3 \mathrm{o}$

Input 4: Milling capacity $\sum \mathrm{n} x 4 \mathrm{n} \lambda \mathrm{n}+\mathrm{IS} 4=x 4 \mathrm{o}$

Input 5: land area $\sum \mathrm{n} x 5 \mathrm{n} \lambda \mathrm{n}+$ IS5 $=x 50$

Index Description:

$\begin{array}{ll}\mathrm{n}=\text { DMUs }, & \mathrm{n}=1, . ., 13 \\ \mathrm{j}=\text { output }, & \mathrm{j}=1, . ., 2 \\ \mathrm{i}=\text { input }, & \mathrm{i}=1, . ., 5\end{array}$

Data Description:

yjn = value of the jth output from DMUto

nxin $=$ value of the jth input from DMU to $n$

$\varepsilon \quad=(10-6)$

yjo dan xio $=$ DMU output and input values that are being observed.

Variabel Description:

$\theta \mathrm{n}=\mathrm{DMU}$ relative efficiency

ISi, OS j $\quad=$ slack from input $\mathrm{i}$, output $\mathrm{j}(\square 0)$

$\square \mathrm{n} \quad=$ weight of DMUn $(\square 0)$ to DMU

\section{b. Scale Efficiency (SE)}

Dual CRS and VRS are used to find Scale Efficiency values. The difference in the technical efficiency output of TECRS and TEVRS shows the value of scale efficiency (SE). If the TECRS value is equal to the TEVRS value, the SE value will be equal to one. But if the SE value is more than one, then the DMU has a scale inefficiency. If TEVRS> SE, changes in efficiency (both increases and decreases) are influenced by pure technical efficiency. However, if TEVRS <SE, the difference in efficiency is caused by scale efficiency development. This calculation is done using MaxDEA 7 Basic software.

\section{c. DEA Variable Analysis}

The large variation of weights received by each period in the production section shows that each variable gives a different contribution. If the variable gets the most significant weight value, it indicates that the variable has 


\section{Procedia Business and Financial Technology}

Proceedings of the 2nd International Conference on Business and M anagement of T echnology (ICO N BM T 2020) - Part 2

more influence on decision making. In contrast, the variable with a small weight value has little effect on decision making at each period in the production department.

d. Determination of an efficient and inefficient DMU

After calculating the technique's efficiency using the Primal DEA CRS model, it will be known which DMUs are considered efficient or inefficient

\section{e. Peer Group Determination}

Peer Group is an efficient grouping of units with inefficient units, to provide direction for improvement for inefficient units. The Peer Group was formed to determine the direction of efficiency improvements for inefficient DMUs and as one of the DEA's improvement techniques. The determination of the Peer Group is done using MaxDEA 7 Basic software.

\section{RESULT}

Based on the analysis results, variables that significantly affect inefficiency are labor variables with a mean percentage of $36 \%$, electricity costs by $25 \%$, and production capacity of $18 \%$. In comparison, two other variables that did not significantly influenceinefficiency were production variables with a $7 \%$ percentage and a land area of $6 \%$. Variables that do not affect inefficiency are land area.

Factors involved in the production efficiency measurement model are the condition of existing companies, business processes, production processes, and input-output variables used to measure production efficiency. The variables consist of land area, milled sugar cane, production capacity, electricity costs, labor, and production. Based on the calculation of technical efficiency (TECRS), there are five sugar mills of PT Perkebunan Nusantara XI that have reached the optimum level of efficiency (efficiency value 1). Based on the calculation of technical efficiency (TEVRS), there are ten sugar factories of PT Perkebunan Nusantara XI that have reached the optimum level of efficiency(efficiency value 1). Based on the calculations and peer group decisions obtained by several factories that are being referenced, including the Pagottan Sugar Factory, Panji, Prajekan, Wonolangan, and Wringin Anom. . Variables that significantly influence PT Perkebunan Nusantara XI's sugar mills' inefficiency are labor, electricity costs, and production capacity variables. By using the DEA method, we get an improvement target for inefficient DMU (sugar mills).

\section{ACKNOWLEDGMENT}

$178 / 180$

We would like to show the great appreciation to Busines Management Departement, Institut Teknologi Sepuluh Nopember for giving the research funding on this topic.

\section{REFERENCES}

[1] S. Deny, "Ekonomi," 24 April 2014. [Online]. Available:https://www.liputan6.com/bisnis/read/20 42901/r i- terancam-jadi-importir-gula-keduaterbesar- dunia.

[2] Katadata, "Statistik," 09 Januari 2019. [Online]. Available:https://databoks.katadata.co.id/datapubli sh/2019/ 01/09/indonesia-importir-gula-terbesardunia- 20172018. [Accessed 18 Maret 2019].

[3] V. F. Thomas, "Ekonomi," 17 Januari 2019. [Online]. Available: https://tirto.id/produksi-gulastagnan-hanya-akal-akalan-pemerintah-untukimpor-dez4.

[4] Direktorat Jenderal Perkebunan, "Statistik Perkebunan Indonesia 2015-2017," 2016. [Online]. Available: Direktorat Jenderal Perkebunan. (2016). Statistik Perkebunan Indonesia 2015-2017. Kementerian Pertanian, Direktorat Jenderal Perkebunan. Jakarta: Sekretariat Direktorat Jenderal Perkebunan. Dipetik April 22, 2019, dari http://ditjenbun.pertanian.go.id/tin.

[5] Sekretariat Dewan Gula Indonesia, "Rencana Operasional Pemecahan," 2010.

[6] BUMN, "Profil Singkat Perusahaan," 2018. [Online]. Available: http://www.bumn.go.id/ptpn11/halaman/2.

[7] R. Satrianegara, "Berita," 23 Maret 2019. [Online]. Available:https://www.cnbcindonesia.com/news/20 180329 141323-4-9046/kinerja-pabrik-gulatradisional- rendah-ini-buktinya.

[8] M. D. Hadad, S. Wimboh, I. Dhaniel and M. Eugenia, "Analisis efisiensi industri perbankan Indonesia: Penggunaan Metode Nonparametrik Data Envelopment Analysis," Working Paper Bank Indonesia, 2003.

[9] M. J. Farrell, "The measurement of Produktive Eficiency," Journal of the Royal Statistical Society, pp. 253-290, 1957.

[10] A. Filardo, N. P. Negoro and A. Kunaifi, "Data Envelopment Analysis dalam Pengukuran Efisiensi Retailer Produk Kendaraan Merek Toyota," Jurnal Sains dan Seni ITS, p. 12, 2017.

[11] O. Havrylchyk, "Efficiency of the Polish banking industry: Foreign versus domestic banks," Journal of Banking \& Finance, pp. 1975-1996, 2006. 


\section{Procedia Business and Financial Technology \\ Proceedings of the 2 nd International Conference on Business and M anagement of T echnology (ICON BM T 2020) - Part 2}

[12] A. Charnes, W. W. Cooper and E. Rhodes, "Measuring the Efficiency of Decision," European Journal of Operational Research, pp. 429-444, 1978. 